\title{
PENGARUH KEGIATAN TUTOR SEBAYA DALAM MENINGKATKAN PRESTASI BELAJAR SISWA YANG MENGALAMI KESULITAN BELAJAR \\ PADA MATA PELAJARAN GEOGRAFI KELAS XI IPS DI SMA NEGERI 1 SAKRA TAHUN PELAJARAN 2020/2021
}

\author{
Muti Hidayati \\ SMA Negeri 1 Sakra \\ Email : muti.hidayati1970@gmail.com
}

\begin{abstract}
ABSTRAK
Penelitian ini ditujukan untuk mengetahui seberapa besar peningkatan hasil belajar siswa setelah diterapkan metode tutor sebaya pada mata pelajaran geografi kelas XI SMA Negeri 1 Sakra. Penelitian ini merupakan jenis penelitian tindakan kelas, dengan metode pembelajaran yang diterapkan adalah metode tutor sebaya. Subjek penelitian adalah siswa kelas XI SMA Negeri 1 Sakra tahun pelajaran 2020/2021 yang berjumlah sebanyak 20 orang siswa. Variabel yang diamati dan diukur adalah hasil belajar siswa. Teknik pengumpulan data dalam penelitian ini menggunakan tes objektif. Analisis data yang dilakukan dengan analisis statistika dengan rumus Uji t one group.

Hasil penelitian menunjukkan bahwa metode tutor sebaya dapat meningkatkan hasil belajar siswa kelas XI IPS pada mata pelajaran geografi. Hasil belajar siswa meningkat terbukti dari perhitungan dimana nilai thitung yang diperoleh dari penelitian ini adalah 13,11, sedangkan nilai table dengan taraf signifikan $5 \%$ dan d.b $=\mathrm{N}-1=20-1=19$ adalah 1,73 . Kenyataan ini menunjukkan bahwa nilai $\mathrm{t}$ hitung yang diperoleh dalam penelitian ini adalah lebih besar dari pada nilai $\mathrm{t}$ tabel $(13,11>1,73)$. Sehingga dengan demikian, nilai t dinyatakan signifikan.
\end{abstract}

Kata Kunci : Metode Tutor Sebaya, Kesulitan Belajar siswa, Hasil Belajar Siswa.

\section{ABSTRACT}

This study was aimed to determine how much improvement in student learning outcomes after the peer tutoring method was applied to the geography subject of class XI SMA Negeri 1 Sakra. This research is a type of classroom action research, with the learning method applied is the peer tutor method. The research subjects were students of class XI SMA Negeri 1 Sakra for the academic year 2020/2021, totaling 20 students. The variables that were observed and measured were student learning outcomes. The data collection technique in this study used an objective test. Data analysis was carried out by statistical analysis with the one group $t$ test formula.

The results showed that the peer tutoring method could improve student learning outcomes in class XI IPS in geography. Student learning outcomes increased as evidenced by the calculation where the t-count value obtained from this study was 13.11 , while the table value with a significant level of $5 \%$ and d.b $=\mathrm{N}-1=20-1=19$ was 1.73 . This fact indicates that the t-count value obtained in this study is greater than the $t$-table value $(13.11>1.73)$. Thus, the value of $t$ is declared significant.

Keywords: Peer Tutor Method, student learning difficulties, student learning outcomes. 


\section{PENDAHULUAN}

Dalam penyelenggaraan proses belajar mengajar pada umumnya, sering dilakukan secara klasikal dimana seluruh siswa dalam kelas dipandang sebagai suatu kelompok besar yang acapkali cara-cara mengajar tidak disesuaikan dengan kemampuan rata-rata siswa. Sehingga dengan demikian, siswa yang lambat merasa tertinggal, dan siswa yang berjalan cepat (pandai) terpaksa tertahan kemajuannya. Keadaan ini tentu merupakan keadaan yang kurang menguntungkan bagi siswa yang pandai maupun siswa yang mengalami kesulitan belajar, yang akhirnya berimbas pula kepada pencapaian hasil prestasi belajar siswa.

Bagi siswa yang pandai, guru perlu memberikan tambahan kegiatan pengayaan atau latihan dan sebagainya, agar sisa waktu yang mereka miliki dapat dimanfaatkan untuk mengembangkan kemampuannya secara optimal. Sedangkan bagi siswa yang mengalami kesulitan belajar diberikan remedial. Siswa yang pandai biasanya lebih cepat dalam menyelesaikan tugastugasnya. Apabila mereka tidak diberikan tugas lain ia akan mengganggu suasana kelas, atau mengganggu teman-temannya yang sedang belajar. Selama ini untuk menangani siswa yang demikian, kadang-kadang guru menangani dengan cara yang keliru, bagi siswa yang sudah jadi pekerjaannya dibiarkan saja tanpa ada tugas lain sambil menunggu teman-temannya yang lain, atau bagi yang sudah selesai duluan boleh pulang. Hal seperti ini akan sangat merugikan, baik bagi siswa yang cepat itu sendiri, maupun bagi siswa yang lambat. Bagi siswa yang cepat menyelesaikan pekerjaannya, mereka banyak membuang waktu hanya untuk menunggu guru memeriksa pekerjaannya, atau menunggu siswa lain yang belum menyelesaikan pekerjaannya, atau bahkan disuruh pulang duluan seperti yang diceritakan diatas. Sedangkan bagi siswa yang lambak, mereka akan panik karena melihat siswa yang lain sudah pulang, mereka akan mengerjakan tugasnya dengan tergesa-gesa atau menyontek dari teman lain.

Oleh karena itu, agar anak yang lambat dapat dibantu, sedang anak yang cepat (pandai) kemampuannya dapat berkembang terus, maka anak yang pandai dapat dimanfaatkan untuk membantu temannya yang lambat, misalnya memberikan petunjuk cara mengerjakannya apabila temannya memperoleh kesulitan. Seperti yang dikatakan oleh Miller (dalam Djalil dkk, 2004 : 3.45) bahwa "Setiap murid memerlukan bantuan dari murid yang lainnya, dan murid dapat belajar dari murid yang lainnya". Pendapat ini menyadarkan kita pada sifat kodrat manusia sebagai mkhluk social yang saling membantu dan saling membutuhkan. Begitu pula dengan mereka, kalau kita amati dalam setiap kelas, pasti ada murid yang bertanya-tanya kepada murid yang lain, atau bahkan berusaha untuk menyontek. Ini menunjukkan bahwa mereka perlu teman dan perlu bantuan. Peran murid yang memberikan bantuan kepada murid lain yang mengalami kesulitan belajar (lambat) inilah yang dinamakan peran tutor sebaya.

Dalam konteks permasalahan sebagaimana digambarkan diatas, maka metode tutorial sebagai suatu upaya dalam pendekatan strategi belajar mengajar yang efektif, memegang peranan penting, khususnya dalam rangka pencapaian hasil belajar yang optimal. Menurut Estiningsih (1997 : 4), "Seseorang siswa yang mengalami kesulitan belajar pada umumnya tidak dapat mencapai hasil belajar yang optimal". Penyebabnya dapat berasal dari siswa, lingkungan sekolah, atau dari lingkungan diluar sekolah. Sebagian besar kesulitan belajar yang akan dibahas pada kesempatan ini adalah yang penyebabnya berasal dari lingkungan sekolah dan khususnya dalam pelajaran Geografi.

Geografi sebagai ilmu yang mempelajari/ mengkaji tentang bumi dan segala sesuatu yang ada diatasnya seperti penduduk, flora, fauna, iklim, udara dan segala intraksinya (Wardiyatmoko, 2004 : 1), diakui merupakan mata pelajaran yang tidak mudah dipelajari. Apabila ada kesan dari sebagian siswa bahwa pelajaran geografi merupakan pelajaran hafalan yang kadang-kadang menjemukan bagi siswa. Hal ini tentu tidak seluruhnya benar dan sifatnya sangat subjektif. Bukan semata-mata pelajaran hafalan dan sebagainya, melainkan banyak faktor yang menyebabkan kesulitan belajar tersebut. Oleh karena itu, usaha membantu siswa menanggulangi kesulitan belajar yang mereka hadapi, khususnya pada mata pelajaran Geografi dapat dilakukan dengan metode tutorial yakni kegiatan tutor sebaya yang diharapkan mampu membelajarkan siswa, 
serta memberikan motivasi dan pelayanan khusus pada saat yang tepat dan sesuai dengan kebutuhan siswa.

Kegiatan tutor sebaya ini dalam pembelajaran remidial merupakan usaha pencegahan atau merupakan usaha penyembuhan/ perbaikan dari kesalahan atau kesulitan yang terjadi dalam belajar. Korelasi dari kegiatan tutor sebaya ini terhadap pencapaian prestasi belajar siswa, tentunya menjadi hal yang sangat menarik bagi peneliti untuk melakukan penelitian dan mengangkat judul "Pengaruh Kegiatan Tutor Sebaya Dalam Meningkatkan Prestasi Belajar Siswa Pada Mata Pelajaran Geografi Di Kelas XI IPS SMAN 1 Sakra Tahun Pelajaran 2020/2021.

Berdasarkan latar belakang diatas, maka dapat dirumuskan rumusan masalah sebagai berikut : Apakah ada pengaruh kegiatan tutor sebaya dalam meningkatkan prestasi belajar siswa yang mengalami kesulitan belajar pada mata pelajaran Geografi di kelas XI IPS SMAN 1 Sakra Tahun Pelajaran 2020/2021?

\section{KAJIAN PUSTAKA}

\section{Tutor Sebaya}

Tutor sebaya adalah seseorang siswa yang membantu belajar siswa lainnya dalam tingjat kelas yang sama (Djalil, 2004 : 3.50). sedangkan menurut Mukhtar dan Rusmini (2005 : 74) tutor sebaya diartikan sebagai bantuan perbaikan yang diberikan oleh siswa-siswa sekelas kepada siswasiswa yang mengalami kesulitan belajar. Berdasarkan kedua pendapat tersebut, maka dapat ditarik kesimpulan tentang pengertian tutor sebaya yakni kegiatan bantuan perbaikan belajar yang dilakukan oleh siswa kepada siswa lainnya dalam kelas yang sama.

\section{Tutor Sebaya Sebagai Metode Pengajaran}

Proses belajar mengajar dalam suatu intraksi guru dengan siswa merupakan salah satu tugas pokok guru. Dalam intraksi yang dimaksud, keaktifan para siswa harus selalu diciptakan, mengingat bahwa siswa bukan hanya sebagai objek, akan tetapi sekaligus sebagai subjek dalam proses pendidikan. Untuk keperluan dimaksud, guru dapat menggunakan berbagai macam metode mengajar yang tepat sesuai dengan materi pelajaran yang akan diajarkan. Salah satu metode mengajar tersebut adalah metode tutorial. Metode tutorial merupakan metode yang digunakan dalam pembelajaran oleh guru dengan memanfaatkan orang lain sebagai tutor untuk membantu siswasiswa dalam belajar (Rahman, 2006 : 15). Pendapat ini memberikan penekanan pada upaya yang dilakukan oleh guru untuk mencapai tujuan pembelajaran dengan memanfaatkan sumbersumber pendidikan yang ada seperti siswa, guru, dan pegawai serta masyarakan sebagai tutor.

Menurut Djalil (2004 : 3.45), tutor merupakan orang yang dipilih dari siswa atau orang lain, yang mempunyai kemampuan lebih untuk membantu siswa lain dalam belajar. Oleh karena itu dalam menentukan tutor, guru tidak asalasalan memilih orang atau siswa sebagai tutor, melainkan orang atau siswa yang betul-betul menguasai materi pelajaran.

Bagi tutor yang diambil dari siswa, mereka harus lebih pandai dari siswa yang lainnya. Sedangkan kalau tutor yang dipilih dari masyarakat, mereka harus mempunyai keahlian khusus yang dapat ditularkan kepada siswa-siswa. Tutor yang diambil dari siswa-siswa sekelas untuk membantu siswa-siswa lainnya dinamakan tutor sebaya. Sedangkan tutor yang diambil dari siswasiswa pada kelas yang lebih tinggi (kakak kelas) dinamakan tutor kakak. Kemudian kalau tutor yang diambil dari masyarakan dinamakan tutor tamu. Tutor-tutor ini, baik tutor sebaya, tutor kakak, maupun tutor tamu, bukanlah untuk menggantikan guru dalam mengajar, melainkan hanya untuk memperpanjang tangan guru dalam membantu murid lain dalam mengajar. Siswa yang dipilih sebagai tutor adalah siswa yang telah tuntas terhadap bahan pelajaran yang akan ditutorkan dengan memperhatikan hal-hal sebagai berikut : (1) menyangkut prestasi, yaitu : pintar, siswa yang termasuk maju dikelasnya, (2) menyangkut penampilan, yaitu : luwes, dapat bergaul dengan semua siswa, dan (3) menyangkut mental, yaitu : ramah, tidak pemarah dan sabar.

\section{Kesulitan Belajar}

Dalam proses pembelajaran di sekolah, aktivitas belajar tidak selamanya dapat berjalan dengan lancar. Masalah kesulitan belajar ini sudah merupakan masalah umum yang terjadi dalam proses pembelajaran. Untuk memahami pengertian kesulitan belajar ini, ada baiknya kita ambil pendapat dari para ahli pendidikan antara 
lain : Hallahan, Kauffman dan Lioyd (dalam Mukhtar dan Rusmini, 2005 : 41) sebagai berikut : Kesulitan belajar khusus adalah gangguan dalam satu atau lebih dari proses psikologis dasar yang mencakup pemahaman dan penggunaan bahasa ujaran atau tulisan. Gangguan tersebut mungkin menampakkan diri dalam bentuk kesulitan mendengarkan, berpikir, berbicara, membaca, menulis, mengeja, atau menghitung.

Batasan tersebut mencakup kondisi-kondisi seperti gangguan perspektual, luka pada otak, disleksia, dan afasia perkembangan. Batasan tersebut tidak mencakup anak-anak yang memiliki problema belajar yang penyebab utamanya berasal dari adanya hambatan dalam penglihatan, pendengaran, atau motorik, hambatan karena tuna grahita, karena gangguan emosional, atau karena kemiskinan lingkungan, budaya atau ekonomi.

\section{Faktor-Faktor Penyebab Kesulitan Belajar}

Aktivitas belajar merupakan inti kegiatan di sekolah, sebab semua aktivitas belajar dimaksudkan untuk mencapai keberhasilan proses belajar bagi setiap siswa yang sedang menjalani studi di sekolah tersebut. Namun, aktivitas belajar bagi siswa terkadang mengalami kesulitankesulitan. Faktor-faktor yang mempengaruhi aktivitas belajar banyak jenisnya, tetapi dapat digolongkan menjadi dua golongan saja, yaitu faktor intern dan ekstern. Faktor intern adalah faktor yang ada dalam diri individu yang sedang belajar, sedangkan faktor ekstern adalah faktor yang ada diluar individu (Slameto, 1995 : 54).

\section{Mengatasi Kesulitan Belajar}

Mengatasi kesulitan belajar yang dialami oleh siswa, tidak dapat dibicarakan secara terpisah dengan faktor-faktor penyebab kesulitan belajar tersebut. Dengan demikian, mencari sumber penyebab utama dan lainnya adalah mutlak bagi seorang guru dalam upaya mengatasi kesulitan belajar yang dialami oleh siswa. Upaya perbaikan kesulitan belajar siswa ini dapat dilakukan dengan memperhatikan apabila ada lebih dari satu siswa yang mengalami kesulitan belajar yang sama, maka upaya perbaikan ini hendaknya diberikan terhadap kelompok siswa secara bersama-sama. Akan tetapi, apabila ada siswa yang memiliki kesulitan belajar yang khusus yang sifatnya unik, maka upaya perbaikan hendaknya diberikan secara individual.

\section{Masalah Prestasi Belajar}

Prestasi belajar merupakan rangkaian dua perkataan yang terdiri dari kata prestasi dan belajar yang masing-masing memiliki pengertian tersendiri, yang setelah dirangkaikan menjadi satu triminologi berubah dengan memiliki pengertian tersendiri pula. Oleh karena itu, sebelum menjelaskan pengertian prestasi belajar, perlu dijelaskan pengertian tentang perkataan belajar agar lebih mudah memahami tentang pengertian prestasi belajar. Aqip (2003 : 43) menjelaskan belajar adalah proses perubahan di dalam diri manusia. Sedangkan dalam karya dijelaskan oleh Fajar (2004 : 10) bahwa belajar merupakan suatu proses perubahan dari diri seseorang yang ditampakkan dalam bentuk peningkatan kualitas dan kuantitas tingkah laku yang lebih baik. Oleh Muhajir (2003 : 1-2) ini disebut sebagai prilaku terpuji atau watak terpuji yakni agar anak menjadi pandai, agar orang tua menjadi ahli, agar orang berkepribadian yang luhur, toleran dan sebagainya. Lebih lanjut Muhajir mengatakan tujuan baik dengan jalan tidak baik bukanlah aktivitas belajar karena tujuan yang menghalalkan segala cara/ jalan yang tidak baik bukanlah semboyan yang bersemangatkan pendidikan.

Prestasi belajar adalah hasil yang diperoleh tentang kemajuan dan perkembangan seseorang (siswa, mahasiswa) dalam segala hal yang menyangkut kualitas dan kuantitas tingkah lakunya )meliputi aspek kognitif, afektif, dan psikomotor) yang lebih baik sebagai akibat dari aktivitas belajar. Ini berarti prestasi belajar tidak akan bias diketahui tanpa dilakukan penilaian atas hasil aktivitas belajar siswa. Fungsi aktivitas belajar bukan saja untuk mengetahui sejauh mana kemajuan siswa setelah menyelesaikan suatu aktivita, tetapi yang lebih penting adalah sebagai alat memotivasi setiap siswa agar lebih giat lagi belajar, baik secara individu maupun kelompok. Sedangkan penilaian itu sendiri adalah terjemahan dari kata evaluasi yaitu suatu tindakan atau proses untuk menentukan nilai dari sesuatu (Wand dan Brown dalam Djamarah, 1994 : 25).

Sesuai pendapat diatas maka evaluasi pendidikan dapat diartikan sebagai suatu tindakan atau suatu proses untuk menentukan nilai segala sesuatu dalam dunia pendidikan atau segala sesuatu yang ada hubungannya dengan dunia pendidikan. 
Evaluasi merupakan salah satu kegaitan yang menjadi kewajiban bagi setiap guru. Evaluasi atau penilaian diharapkan untuk memberikan informasi tentang kemajuan yang telah dicapai oleh siswa, sampai dimana penguasaan dan kemampuan yang siswa dapatkan setelah mempelajari suatu mata pelajaran. Disinilah ketetapan penyusunan strategi penilaian diperlukan dan menentukan bagaiman intensitas prestasi belajar siswa. Hal ini berhubungan dengan salah satu kemampuan guru mengenai penilaian terhadap prestasi belajar siswa. Guru yang tidak tepat dalam penyusunan strategi penilaian akan mendapatkan hasil penilaian yang bias, yang menyebabkan informasi yang diterimapun tidak akurat.

\section{METODE PENELITIAN}

Metode yang dipergunakan untuk memecahkan masalah ini adalah metode penelitian deskriftif kuantitatif. Penelitian deskriftif itu sendiri merupakan penelitian yang diarahkan untuk memberikan gejala-gejala, fakta-fakta atau kejadian-kejadian yang secara sistematis dan akurat, mengenai sifat-sifat populasi atau daerah tertentu (Riyanto, 2001 : 23). Sedangkan rencana penelitian ini menggunakan pendekatan kuantitatif yaitu suatu proses menemukan pengetahuan yang menggunakan data berupa angka sebagai alat menemukan keterangan mengenai apa yang ingin kita ketahui (Margono, 2003 : 105-106). Adapun pendekatan yang digunakan dalam metode penelitian diskriftif ini adalah pendekatan eksperimen, yakni suatu pendekatan dimana situasi atau gejala dibuat dengan sengaja (Arikunto, 2002 : 95). Atau dengan kata lain, gejala yang akan diteliti akan dibuat menjadi kelas eksperimen yangkni kelas yang akan diberikan perlakuan.

Dalam penelitian ini, siswa-siswa yang mempunyai prestasi belajar yang rendah pada mata pelajaran geografi akan di data, kemudian akan dikumpulkan dalam suatu kelas yang kemudian disebut kelas eksperimen. Siswa-siswa yang mempunyai prestasi belajar yang rendah tersebut kemudian akan diberikan perlakuan yaitu diberika remedial atau pengayaan materi dengan metode tutor sebaya. Kemudian setelah diberikan remedial, lalu akan diberikan soal tes yang sesuai dengan materi yang diremidialkan.

\section{HASIL PENELITIAN}

Sebagaimana yang telah dibahas pada bab sebelumnya bahwa subyek penelitian ini adalah sejumlah siswa kelas XI IPS SMA Negeri 1 Sakra yang tergolong lemah atau lambat belajarnya dalam pelajaran geografi dan memiliki nilkai di bawah 72 pada semester 2020/2021. Nama-nama siswa yang terjaring sebagai sampel pada penelitian ini adalah sejumlah 20 orang untuk keseluruhan kelas XI IPS yang berasal dari kelas XI IPS $1=6$ orang, kelas XI IPS $2=7$ orang, dan kelas XI IPS $3=7$ orang.

Untuk mendiskripsikan pengaruh adanya kegiatan tutor sebaya terhadap peningkatan prestasi belajar siswa dapat dilakukan dengan membandingkan atau mengkomparasikan nilai perubahan sesudah dan sebelum adanya kegiatan remedial dengan metode tutor sebaya. Adapun nilai prestasi belajar siswa sebelum dan sesudah remedial dengan metode tutor sebaya ini dapat didiskrifsikan dalam bentuk tabel 03 berikut ini :

$$
\text { Tabel } 03
$$

Prestasi Belajar Siswa Sebelum Diberikan Remedial Dengan Metode Tutor Sebaya Pada Mata Pelajaran Geografi Kelas XI IPS SMA Negeri 1

Sakra Tahun Pelajaran 2020/2021

\begin{tabular}{|l|l|c|c|}
\hline No & \multicolumn{1}{|c|}{ Nama Siswa } & Kelas & $\begin{array}{c}\text { Prestasi } \\
\text { Belajar } \\
\text { Sebelum } \\
\text { Remedial }\end{array}$ \\
\hline 1 & Haris Pratama & XI IPS 1 & 70 \\
\hline 2 & $\begin{array}{l}\text { Muhammad } \\
\text { Hamzani }\end{array}$ & XI IPS 1 & 60 \\
\hline 3 & Muh. Silpfan Halipi & XI IPS 1 & 70 \\
\hline 4 & $\begin{array}{l}\text { Taufik } \\
\text { Hidayatullah }\end{array}$ & XI IPS 1 & 60 \\
\hline 5 & Widiana & XI IPS 1 & 70 \\
\hline 6 & Ika Nurmayatin & XI IPS 1 & 70 \\
\hline 7 & Hasan Wira Bakti & XI IPS 2 & 70 \\
\hline 8 & Hamdi Susanto & XI IPS 2 & 60 \\
\hline 9 & $\begin{array}{l}\text { Rifki Ananta } \\
\text { Budiman }\end{array}$ & XI IPS 2 & 60 \\
\hline 10 & Junaidi Artoni & XI IPS 2 & 70 \\
\hline 11 & Saipul Aswadi & XI IPS 2 & 70 \\
\hline 12 & Melsi Widiasari & XI IPS 2 & 70 \\
\hline 13 & Susilawati & XI IPS 2 & 70 \\
\hline 14 & Sopian Humaidi & XI IPS 3 & 60 \\
\hline 15 & Taopan Samudra & XI IPS 3 & 60 \\
\hline 16 & Dodi Iskandar & XI IPS 3 & 70 \\
\hline 17 & Hasnila Ermayana & XI IPS 3 & 70 \\
\hline
\end{tabular}




\begin{tabular}{|l|l|l|l|}
\hline 18 & Isratul Oktavia & XI IPS 3 & 70 \\
\hline 19 & Ikhwan Juliardi & XI IPS 3 & 70 \\
\hline 20 & Supriadi & XI IPS 3 & 60 \\
\hline
\end{tabular}

Sumber Data : SMA Negeri 1 Sakra

Subyek penelitian ini kemudian akan diberikan pengayaan materi (remedial) oleh guru mata pelajaran dengan bantuan dan bimbingan dari teman-teman sekelasnya atau dengan metode tutor sebaya. Siswa-siswa yang dipilih sebagai tutor ini adalah siswa yang pandai dan ditunjuk oleh guru mata pelajaran geografi. Setelah diberikan pengayaan materi (remedial), kemudian diberikan test. Hasil test sesudah remedial dengan metode tutor sebaya ini dapat dilihat dalam tabel 04 berikut ini :

Tabel 04

Prestasi Belajar Siswa Sesudah Diberikan Remedial Dengan Metode Tutor Sebaya Pada Mata Pelajaran Geografi Kelas XI IPS SMA Negeri 1 Sakra Tahun Pelajaran 2020/2021

\begin{tabular}{|l|l|l|c|}
\hline NO & \multicolumn{1}{|l|}{ Nama Siswa } & Kelas & $\begin{array}{c}\text { Prestasi } \\
\text { Belajar } \\
\text { Sebelum } \\
\text { Remedial }\end{array}$ \\
\hline 1 & Haris Pratama & XI IPS 1 & 85 \\
\hline 2 & $\begin{array}{l}\text { Muhammad } \\
\text { Hamzani }\end{array}$ & XI IPS 1 & 75 \\
\hline 3 & Muh. Silpfan Halipi & XI IPS 1 & 80 \\
\hline 4 & $\begin{array}{l}\text { Taufik } \\
\text { Hidayatullah }\end{array}$ & XI IPS 1 & 80 \\
\hline 5 & Widiana & XI IPS 1 & 75 \\
\hline 6 & Ika Nurmayatin & XI IPS 1 & 80 \\
\hline 7 & Hasan Wira Bakti & XI IPS 2 & 80 \\
\hline 8 & Hamdi Susanto & XI IPS 2 & 80 \\
\hline 9 & $\begin{array}{l}\text { Rifki Ananta } \\
\text { Budiman }\end{array}$ & XI IPS 2 & 75 \\
\hline 10 & Junaidi Artoni & XI IPS 2 & 75 \\
\hline 11 & Saipul Aswadi & XI IPS 2 & 85 \\
\hline 12 & Melsi Widiasari & XI IPS 2 & 80 \\
\hline 13 & Susilawati & XI IPS 2 & 85 \\
\hline 14 & Sopian Humaidi & XI IPS 3 & 80 \\
\hline 15 & Taopan Samudra & XI IPS 3 & 75 \\
\hline 16 & Dodi Iskandar & XI IPS 3 & 85 \\
\hline 17 & Hasnila Ermayana & XI IPS 3 & 80 \\
\hline 18 & Isratul Oktavia & XI IPS 3 & 80 \\
\hline 19 & Ikhwan Juliardi & XI IPS 3 & 85 \\
\hline 20 & Supriadi & XI IPS 3 & 80 \\
\hline Sul & Data SMA Negeri & Sakra \\
\hline
\end{tabular}

Sumber Data : SMA Negeri 1 Sakra

\section{Analisis Data}

Langkah-langkah yang ditempuh dalam penelitian ini adalah : (1) Merumuskan hipotesis nihil (Ho), (2) Membuat tabel kerja, (3) Memasukkan data ke dalam rumus t-test, (4) Menguji nihil t-test, dan (5) Menarik kesimpulan.

\section{Merumuskan Hipotesis Nihil (Ho)}

Untuk keperluan perhitungan analisis statistic, maka hipoteisis alternatif $(\mathrm{Ha})$ yang diajukan yang diajukan pada bab I yang berbunyi : "Ada perbedaan prestasi belajar siswa yang mengalami kesulitan belajar sebelum dan sesudah dilakukan remedial dengan metode tutos sebaya pada mata pelajaran geografi kelas XI IPS SMA Negeri 1 Sakra tahun pelajaran 2020/2021", maka perlu diubah terlebih dahulu ke dalam sebuah hipotesis nol (Ho) sehingga berbunyi : "Tidak ada perbedaan prestasi belajar siswa yang mengalami kesulitan belajar sebelum dan sesudah dilakukan remedial dengan metode tutor sebaya pada mata pelajaran geografi kelas XI IPS SMA Negeri 1 Sakra tahun pelajaran 2020/2021.

\section{Menguji Signifikansi t-test}

Dari hasil perhitungan ternyata nilai $t$ hitung yang diperoleh dalam penelitian ini adalah 13,11 , sedangkan nilai $t$ tabel dengan signifikansi $5 \%$ dan d.b $=\mathrm{N}-1=20-1=19$ adalah 1,37. Kenyataan ini menunjukkan bahwa nilai t hitung yang diperoleh dalam penelitian ini adalah lebih besar dari nilai. Dari hasil pengujian $t$ di atas, dimana $t$ hitung lebih besar dari $t$ tabel $(13,11>$ $1,73)$ sehingga nilai t dinyatakan signifikan. Hal ini berarti hipotesis nol (Ho) ditolak atau hipotesis alternatif (Ha) diterima. Maka kesimpulan analisis dari penelitian ini adalah : "Ada perubahan prestasi belajar siswa yang mengalami kesulitan belajar sebelum dan sesudah diberikan remedial dengan metode tutor sebaya pada mata pelajaran geografi kelas XI IPS SMA Negeri 1 Sakra tahun pelajaran 2020/2021.

\section{PEMBAHASAN}

Dari hasil pengujian hipotesis menunjukkan bahwa : Ada perubahan prestasi belajar siswa yang mengalami kesulitan belajar sebelum dan sesudah diberikan remedial dengan metode tutor sebaya pada mata pelajaran geografi 
kelas XI IPS SMA Negeri 1 Sakra tahun pelajaran 2020/2021. Dengan demikian, dapat dikatakan bahwa dengan adanya kegiatan tutor sebaya, prestasi belajar siswa yang mengalami kesulitan belajar menjadi meningkat. Prestasi belajar siswa sebelum adanya kegiatan remedial dengan metode tutor sebaya, masih terdapat siswa yang mempunyai nilai di bawah 72 , dan setelah adanya kegiatan remedial dengan metode tutor sebaya, maka tidak terdapat lagi siswa yang mempunyai prestasi belajar di bawah 72. Hal ini menandakan bahwa kegiatan remedial dengan metode tutor sebaya mempunyai pengaruh yang nyata terhadap peningkatan prestasi belajar siswa. Oleh karena itu, dapat dikatakan disini bahwa ada pengaruh kegiatan tutor sebaya terhadap peningkatan prestasi belajar siswa yang mengalami kesulitan belajar pada mata pelajaran geografi kelas XI IPS SMA Negeri 1 Sakra tahun pelajaran 2020/2021.

\section{KESIMPULAN}

Berdasarkan hasil analisis data dan pembahasan dapat disimpulkan bahwa : Ada pengaruh kegiatan tutor sebaya terhadap peningkatan prestasi belajar siswa yang mengalami kesulitan belajar pada mata pelajaran geografi kelas XI IPS SMA Negeri 1 Sakra tahun pelajaran 2020/2021. Artinya bahwa dengan adanya kegiatan remedial dengan metode tutor sebaya tersebut, prestasi belajar siswa yang mengalami kesulitan belajar menjdi meningkat. Hal ini terbukti dari hasil perhitungan dimana nilai $\mathrm{t}$ hitung yang diperoleh dalam penelitian ini adalah 13,11, sedangkan nilai t tabel dengan taraf signifikasi $5 \%$ dan d.b $=\mathrm{N}-1=20-1=19$ adalah 1,37. Kenyataan ini menunjukkan bahwa nilai t hitung yang diperoleh dalam penelitian ini adalah lebih besar dari pada nilai t tabel $(13,11>1,73)$. Sehingga dengan demikian nilai $\mathrm{t}$ dinyatakan signifikan.

\section{SARAN}

Berdasarkan kesimpulan di atas, penulis dapat mengajukan beberapa saran sebagai berikut : Kepada para guru, sebagai pendidik anak di sekolah juga diharapkan dapat memberikan layanan bimbingan dengan sebaik-baiknya kepada siswa dalam aktivitas belajarnya, sehingga tujuan pendidikan dapat tercapai dengan baik dan lancar sesuai harapan.

Kepada orang tua/ wali murid, dalam rangka menumbuhkan potensi anak, orang tua diharapkan dapat memberikan bimbingan dalam belajar anak dengan baik. Orang tua yang kurang atau tidak memperhatikan pendidikan anaknya, tidak memperhatikan kepentingan-kepentingan dan kebutuhan-kebutuhan anaknya dalam belajar, tidak mengatur waktu belajarnya, tidak memperhatikan kesulitan-kesulitan yang dialami dalam belajar dan lain-lain dapat menyebabkan anak kurang beraktivitas dalam belajarnya.

Kepada siswa disarankan agar belajar dengan tekun baik secara kelompok maupun secara individu, mengerti keadaan orang tua dan berbakti pada mereka. Kepada peneliti lain, diharakan agar mengadakan penelitian yang lebih mendalam dan lebih luas, khususnya mengenai hal-hal yang belum terungkap dalam penelitian ini.

\section{DAFTAR PUSTAKA}

Ahmadi, Abu dan Supriono, Widodo, 1991. Psikologi Belajar. Jakarta : Rineka Cipta.

Aqip, Zainal, 2003. Profesionalisme Guru Dalam Pembelajaran. Surabaya : Isan Cendikia.

Arikunto, Suharsini, 2002. Prosedur Penilaian Suatu Pendekatan Praktik. Jakarta : Rineka Cipta.

Damin, Sudarwan, 1997. Metodologi Penelitian. Jakarta : Rineka Cipta.

Djamarah, Syaiful Bahri, 1994. Prestasi Belajar dan Kompetensi Guru. Surabaya : Usaha Nasional.

Djalil, Aria, dkk, 2004. Pembelajaran Kelas Rangkap. Jakarta : Pusat Penerbitan Universitas Terbuka.

Estiningsih, Elly, 1997. Diagnosis Kesulitan Belajar Siswa. Majalah Mutu Depdikbud RI Vol 1 No 2

Hadi, Sutrisno, 2002. Metode Reseach. Yogyakarta : Fakultas Psikologi UGM

Margono, 2003. Metodologi Penelitian Pendidikan. Jakarta : Rineka Cipta

Rinduwan, 2003. Dasar-Dasar Statistika. Bandung : Alfabeta

Slameto, 1995. Belajar dan Faktor-Faktor Yang Mempengaruhinya. Jakarta : Rineka CiptaSardiman, A.M, 2001. Intraksi dan Motivasi Belajar Mengajar. Jakarta : Rineka Cipta 
Sudjana, 2002. Metode Statistika. Bandung : Tarsito
Sugiyono, 2000. Statistika Untuk Penelitian. Bandung : CV Alfabeta 